\title{
Egyptian Mother-to-fetus transmission of Parvovirus B-19 in the first trimester abortions
}

\author{
Abo-Elkhier AAK ${ }^{1}$ and Abdel-Wahab KSE ${ }^{2}$ \\ 1. Clinical Pathology Department, El-Sahel Teaching Hospital, Ministry of Health. \\ 2. Virology Laboratory, Microbiology Department, Faculty of Medicine, \\ Al-Azhar University, Branch for Females
}

\begin{abstract}
Parvovirus B-19 infection is a common mild illness in adulthood and usually subclinical in childhood. Serious illness can be caused by this virus in certain circumstances. When a pregnant female contracts parvovirus B-19 complications may affect the fetus and/or the newly born. A study of 240 parturient mothers was carried out to assess the possible role of this virus in abortion. Detection of virus-DNA in fetal tissues by PCR confirmed mother-fetus transmission.
\end{abstract}

\section{Introduction}

Parvovirus B-19 (Pattison and Patou, 1996) is a single strand DNA virus of small size that infects humans usually by inhalation, but can be transmitted by blood, blood products, plasma and bone marrow transfusion (Siegl and Cassinolty, 1988). In immunocompetent persons subclinical infection is predominant. The clinical infection of children is erythema infectiosum and of adults are polyarthritis, transient aplastic crisis, and pure red cell aplasia. Infected adult pregnant females in their first trimester, may transmit parvovirus B19 to their fetus where infection of the fetal heart leads to nonimmune hydrops fetalis, and erythrocyte progenitor cell suppression. Parvovirus B19 infects placental endothelia with high titer output that enables the virus to cross the placenta barrier to the fetus where it grows in liver, bone marrow, heart and skin. Multi-organ infection may progress to abortion, still birth or postnatal death (Enders et al. 2004 and Yong et al. 2004). Parvovirus B-19 may cause chronic infection (Frickhofen and Young 1989 and Koch \& Adler 1990).

Parvovirus B19 serological and molecular tests are used to diagnose infection. IgM anti-parvo B19 is a marker of early immune response in acute infection. IgG anti Parvovirus B19 is a marker of past exposure. The enzyme-linked immunosorbent assay (ELISA) test is used to assay these antibodies in patient's sera but not in fetal blood due to the immature immune system response. Detection of Parvovirus B19 - DNA by polymerase chain reaction $(\mathrm{PCR})$ is used to evaluate qualitatively or quantitatively viral DNA. Viremia titer is up to $10^{11}$ to $10^{13}$ genome equivalents $/ \mathrm{ml}$ ). There are variations in Parvovirus B19 PCR results, because of the choices of primer sites, the PCR procedure (Anderson et al., 1985) and the existence of virus variants (Heegaard et al., 2001; Servant et al., 2002; Saldanha et al., 2002; Hokynar et al., 2004). In our study we selected Parvovirus B19 VP1 gene primers for PCR according to Koch and Adler (1990).

\section{Aim of Study}

To assess mother to fetus transmission of parvovirus B-19 when pregnant mothers are hospitalized for spontaneous abortion in the first trimester. 


\section{Study Conditions}

The plan of the study was approved by the ethical committees in both Al-Azhar University and El-Sahel Teaching Hospital. An informed consent was signed by each subject after explaining the purpose of the study.

\section{Pregnant Females}

This study covered 240 Egyptian parturient women aged between 17-41 years who were admitted to Obstetrics and Gynecology Department of Sahel Teaching Hospital, Ministry of Health, Cairo. One hundred and twenty were in labor at full term and 120 were first trimester undergoing spontaneous abortion. Demographic data plus past history of number and outcome of previous pregnancy, febrile illness or jaundice, surgery or dental treatment, intravenous drugs or blood transfusion were recorded. None of these 240 subjects recalled a history of symptoms and signs suggestive of their household contacts infection with parvovirus B19.

\section{Materials and Methods}

\section{Materials:}

\section{Samples}

Maternal venous blood $(10 \mathrm{ml})$ and 3-5 ml of fetal cord vein blood were collected. Aborted fetal tissues were placed in a sterile container with addition of antibacterial and antimycotic drug mixture.

\section{ELISA Kits}

Specific IgM anti parvovirus B19 VP1 (code 57131) kits were from IBL, Germany.

\section{PCR Primers (Koch and Adler, 1990)}

These were:

- K-1 primer (5 - 3') nucleotide numbers 2936 - 2954, and

- K-2 primer (5` - 3`) nucleotide numbers $3617-3635$.
The nucleotides are located in VPI gene sequence and the amplification product is 699 base pair.

\section{Reagents for Biochemical Tests}

Reagents for biochemical analysis were from Boehringer, Germany.

\section{Methods:}

\section{ELISA Test}

The commercial ELISA kit instructions were employed.

\section{Biochemical Analyses}

These included: total and direct bilirubin, total protein, albumin, aspartate aminotransferase (AST) and alanine aminotransferase (ALT), alkaline phosphatase, gamma-glutamyl transferase $(\gamma$-GT), $\alpha$-fetoprotein (AFP), serum iron and total iron binding capacity assays. The standard procedures were done.

\section{Extraction of Parvovirus B19 DNA for PCR}

DNA was extracted directly from $100 \mu$ of each serum sample / or from 1-2 gm aborted fetal tissue by guanidium thiocyanate / phenol / chloroform followed by chloroform / isoamyl alcohol

and was precipitated by ethanol (Chomczynski and Sacchi 1987). The extracted DNA was dissolved in $20 \mu \mathrm{l}$ of diethyl pyrocarbonate (DEPC)-treated water. The mixture was heated at $95^{\circ} \mathrm{C}$ for 5 minutes, then chilled on ice.

\section{Parvovirus B19 DNA PCR}

Two microliters of the extracted sample DNA was combined with $2 \mu \mathrm{l}$ of $1 \mathrm{P} \mathrm{M}$ of each primer (K1 5-ATA AAT CCA TAT ACT CAT T-3') and the sense one (K2 5'CTA AAG TAT CCT GAC CTT G-3`), $5 \mu \mathrm{l}$ $10 \times$ PCR buffer $(500 \mathrm{mM}$ Tris-HCL, $\mathrm{pH}$ $8.3,500 \mathrm{mM} \mathrm{KCl}, 100 \mathrm{mM} \mathrm{MgCl} 2,40 \mathrm{mM}$ Dithiothreitol, (Advanced Biotechnology), $4 \mu \mathrm{l}$ of $2 \mathrm{mM} \mathrm{MgCl}_{2}$ and $2 \mu \mathrm{l}$ of $200 \mu \mathrm{M}$ dNTPs (Promega) in a $50 \mu$ l reaction volume. Taq DNA polymerase (GIBCOBRL) $0.5 \mu l$ containing $2 \mathrm{U}$ was added to the mixture after an initial 3 minutes 
incubation at $94^{\circ} \mathrm{C}$ using Perkin Elmer 9600 thermal cycler. Thirty five rounds of amplification were performed under the following conditions; $94^{\circ} \mathrm{C}$ for 2 minutes, $37^{\circ} \mathrm{C}$ for 2 minutes and $72^{\circ} \mathrm{C}$ for 3 minutes, product was placed in a lane slot with one lane for the DNA molecular weight marker (Ø x 174 DNA / Hinf 1 marker, Promega) for electrophoresis on a $2 \%$ agarose minigel. After staining the gels with ethidium bromide they were viewed under UV light and photographed. Amplicones of 699 bp molecular weight were considered positive amplicones of parvovirus B-19 VP1 gene DNA (Koch and Alder, 1990).

\section{Results}

\section{Parvovirus B19 Serology and PCR}

Table (1) showed that among 120 aborted women only 3 were anti-parvovirus B19 and then followed by one round at $72^{\circ} \mathrm{C}$ for 7 minutes to complete the extension of the primers. After amplification, $10 \mu \mathrm{l}$ of each amplified

IgM antibody positive $(2.5 \%)$, while out of 120 full-term parturient women, one $(0.83 \%)$ was anti-parvovirus B19 IgM positive. This difference was not statistically significant $(\mathrm{P}>0.05)$ and can't be used for differential diagnosis. Only 1 of $120(0.83 \%)$ aborted women had antiparvovirus B19 IgM and virus DNA; however 2 of them $(1.66 \%)$ were parvovirus B19 IgM positive only but negative for virus DNA (Table 2). The serum sample which had high level of antiparvovirus B19 IgM (0.646) ELISA optical density (O.D.) was positive for parvovirus B19 DNA, while the two sera which had ODs lower than 0.600 O.D. were negative for virus DNA.

Table (1): Parvovirus B19 IgM antibody among aborted and full-term parturient women

\begin{tabular}{|l|c|c|c|c|}
\hline \multirow{2}{*}{ Category } & \multicolumn{2}{|c|}{$\begin{array}{c}\text { Aborted Women } \\
(\mathbf{1 2 0} \text { cases })\end{array}$} & $\begin{array}{r}\text { Full Term Delivery Women } \\
\text { (120 cases })\end{array}$ \\
\cline { 2 - 5 } & Number & Percent & Number & Percent \\
\hline $\begin{array}{l}\text { Parvovirus IgM } \\
\text { positive women }\end{array}$ & 3 & 2.5 & 1 & 0.83 \\
\hline $\begin{array}{l}\text { Parvovirus IgM } \\
\text { negative women }\end{array}$ & 117 & 97.5 & 119 & 99.17 \\
\hline Total & 120 & 100 & 120 & 100 \\
\hline P-value & \multicolumn{5}{|c|}{$>0.05$ N.S. } \\
\hline
\end{tabular}

Table (2): Aborted Women IgM Antibody to Parvovirus B19 and Virus DNA

\begin{tabular}{|c|c|c|}
\hline \multirow{2}{*}{ Case No. } & \multicolumn{2}{|c|}{ Mother's Serum } \\
\cline { 2 - 3 } & Anti-parvovirus IgM ELISA* & Viral DNA PCR \\
\hline 35 & +ve $(0.646)$ & $+\mathrm{ve}$ \\
\hline 65 & +ve $(0.515)$ & -ve \\
\hline 104 & +ve $(0.574)$ & -ve \\
\hline
\end{tabular}

* An optical density $(O D)$ reading above the cutoff value of $\operatorname{Ig} M(0.384 \lambda)$ is considered positive. 
Table (3) showed that the level of alpha-fetoprotein in the serum of three parvovirus B $19 \operatorname{IgM}$ positive aborted mothers was higher than the normal value, while it was within the normal range in the sera of 117 parvovirus B 19 IgM negative aborted mothers. This difference was statistically highly significant $(\mathrm{P}>0.01)$. These cases aborted in the first trimester. The $\alpha$ fetoprotein level changes according to gestation age so it was not feasible to derive a solid association with the fate of gestation.

Table (3): Alpha-fetoprotein level in serum of anti-parvovirus B19 IgM positive and negative aborted women

\begin{tabular}{|l|c|c|}
\hline \multicolumn{1}{|c|}{ AFP } & $\begin{array}{c}\text { Anti-parvovirus B19 IgM } \\
\text { positive aborted women } \\
\text { (3 cases) }\end{array}$ & $\begin{array}{c}\text { Anti-parvovirus B19 IgM } \\
\text { negative aborted women } \\
\text { (117 cases) }\end{array}$ \\
\hline Range N: up to 8.5) & $54-72 \mathrm{ng} / \mathrm{ml}$ & $6.2-7.5 \mathrm{ng} / \mathrm{ml}$ \\
\hline Mean & 64 & 7.03 \\
\hline SD \pm & 9.17 & 0.72 \\
\hline P-value & \multicolumn{2}{|c|}{$<0.01$ H.S. } \\
\hline
\end{tabular}

The results of Table (4) indicated that the one anti-parvovirus B19 IgM and virus DNA positive aborted woman transmitted the virus to her fetus. Also though that the two antiparvovirus B19 IgM positive who had no viremia, did transmit the virus to their feti. None of the full-term delivered mothers passed parvovirus B19 to their feti.

Table (4): Comparison of maternal serum parvovirus B19 DNA and anti-parvovirus B19 IgM in aborted fetus tissue with full-term parturient mother fetal cord blood

\begin{tabular}{|l|c|c|c|}
\hline \multirow{4}{*}{ Category } & \multicolumn{2}{|c|}{ Maternal Serum } & Fetal Tissue \\
\cline { 2 - 4 } & $\begin{array}{c}\text { Anti-parvovirus } \\
\text { B19 IgM* }\end{array}$ & $\begin{array}{c}\text { Parvovirus B19 } \\
\text { DNA by PCR }\end{array}$ & $\begin{array}{c}\text { Parvovirus B19 DNA by } \\
\text { PCR }\end{array}$ \\
\hline \multirow{2}{*}{$\begin{array}{l}\text { First trimester } \\
\text { abortion }\end{array}$} & $+\mathrm{ve}(0.646)$ & $+\mathrm{ve}$ & $+\mathrm{ve}$ \\
\cline { 2 - 4 } & $+\mathrm{ve}(0.515)$ & $-\mathrm{ve}$ & $+\mathrm{ve}$ \\
\cline { 2 - 4 } & $+\mathrm{ve}(0.574)$ & $-\mathrm{ve}$ & $+\mathrm{ve}$ \\
\hline Full-term delivery & $+\mathrm{ve}(0.446)$ & $-\mathrm{ve} * *$ & $-\mathrm{ve} * *$ \\
\hline
\end{tabular}

* An optical density $(O D)$ reading above the cutoff value of $\operatorname{IgM}(0.384 \lambda)$ is considered positive.

** The cord blood of the delivered baby was negative for parvovirus B-19 DNA.

\section{Discussion:}

About $50 \%$ of adults have parvovirus B19 IgG antibody which is a marker of past exposure. This proportion increases to more than $90 \%$ in the elderly (Cohen and Buckley, 1988). An annual seroconversion rate of $1.5 \%$ was estimated in a study of serial samples from women of child-bearing age (Koch and Alder, 1990). IgM antiparvovirus B19 is a marker of acute infection (Schwarz et al., 1992 and 1997). A total of 1047 pregnant women in Kuwait had $2.2 \%$ parvo virus B19 IgM. On the other hand, 53.3\% had IgG anti-parvo B19 (Maksheed et al., 1999) similar to 52\% IgG anti-parvovirus B19 seropositive parturient mothers in Egypt (Ibrahim et al., 1993). Ibrahim et al. (1993) detected also IgG anti-parvo virus B19 in 30\% spontaneously aborted women without any IgM reactivity.

There are reports that associate adult female serum parvovirus B19 IgM seropositivity with household or occupational contact 
with parvovirus B19 subclinical/clinical infections of sibling or contact children (Koch and Alder, 1990; Gillespie et al., 1990; Cartter et al., 1991; Ibrahim et al., 1993). If the females were non-immune and pregnant, then transplacental transmission of parvovirus B19 to the fetus mostly in the third and less in the first trimester occurred (Nyman et al., 2002). This was associated with intrauterine death, abortion, multiorgan infection, and non-immune hydrops fetalis, whether the maternal infection was symptomatic or asymptomatic. Placental tissue villuous trophoblast layer provides target cells for parvo virus replication (Jordan and DeLoia, 1999; Nyman et al., 2002; and Quemelo et al., 2007). In our study, IgM antibody seropositivity in first trimester aborting females was 3/120 (2.5\%) and parturient full-term females was $1 / 120(0.83 \%)$ in contrast to the report by Ibrahim et al. (1993). This change in the antibody marker of acute parvovirus B19 infection reflects variations in the seasonal virus infection and also demographic changes. Parvovirus DNA was 1/120 $(0.83 \%)$ in aborting mother's serum but was nil in parturient full-term pregnant mothers.

Detection of viral DNA in aborted fetus tissue is evidence of mother to fetus transmission in the case of $\operatorname{IgM}$ antiparvovirus B19 seropositivity. Viral DNA in aborted tissue was present in $3 / 3(100 \%)$ but nil in full-term delivery cord vein blood. Yet, detection of virus DNA in maternal serum was not a predictive marker of mother to fetus transmission as two serum parvo virus DNA negative mothers passed the infection to their feti. In the study from Kuwait, the rate of fetal loss was $15.4 \%$ in the first two trimester parvovirus B19 infected aborting mothers (Maksheed et al., 1999). This result may have been different if detection of viralDNA data were available for mother-fetus paired samples. Our study weakness is that the subject number is small (240). Our data about some of the salient features of parvovirus B19 mother/fetus/newborn infection-transmission is in concordance with previous publications from developed and developing countries and emphasizes the choice of PCR for viral DNA detection as the most reliable test using fetal tissue. The use of PCR and fetal tissue for detection of human parvovirus B-19 DNA in events of first trimester intrauterine fetal death improved diagnosis. Our experience is in agreement with previous report (Tolvenstam et al., 2001).

In our study, 3/120 (2.5\%) first trimester spontaneously aborted women were positive for anti-parvovirus B19 IgM, while only $1 / 120(0.83 \%)$ full-term delivered women (control group) had IgM anti parvovirus B-19. Our results showed that IgM anti parvovirus B-19 in maternal serum was not predictive of virus transmission to the fetus.

Serum parvovirus B19-DNA was detected in one out of the three anti-parvovirus B19 IgM positive aborted women, while the parvovirus B-19 IgM positive full-term parturient woman was negative for parvovirus B-19 DNA. Nyman et al. (2002) also reported that parvovirus B-19 associated fetal loss in the first trimester should be affirmed by testing the fetal tissue to exclude possible contamination of placental tissue with viremic maternal blood. Our results are based on fetal tissue testing to provide solid diagnosis.

In first trimester abortion current study, the three anti-parvovirus B19 IgM positive aborted woman-fetus pair there was $100 \%$ vertical virus transmission. Whether acute Maternal parvovirus infection (IgM +ve, DNA +ve) or early maternal recovery (IgM +ve, DNA -ve) led to $2.5 \%$ vertical virus transmission and have been the principal cause of spontaneous abortion. Meanwhile, the one anti-parvovirus B19 IgM positive full-term parturient woman and her infant cord serum were both parvovirus B19 DNA negative. This $2.5 \%$ is near the $3 \%$ reported by Nyman et al. (2002).

\section{Conclusion}

There was correlation between markers of maternal acute infection and vertical transmission of parvovirus B19 with fetal wasting in the first trimester pregnancy. We 
recommend premarital screening for immunity to parvovirus B19 and proper counseling of non-immune females. Should a vaccine against parvovirus B19 become available, then the Ministry of Health authorities should consider selective vaccinations for naïve subjects especially when other health problems exist raising the risk of viral infection complications.

\section{References:}

Anderson MJ, Jones SE, Minson AC (1985): Diagnosis of human parvovirus infection by dot-blot hybridization using cloned viral DNA, J. Med. Virol. 15: 163-172.

Cartter ML, Farley TA, Rosengren S, Quinn DL, Gillespie SM et al. (1991): Occupational risk factors for infection with parvovirus B19 among pregnant women. J. Infect. Dis. 163: 282-293.

Chomczynski P and Sacchi N (1987): Singlestep method of isolation of DNA by acid guanidium thiocyanate-phenol-chloroform extraction. Anal. Biochem. 162: 156-159.

Cohen BJ and Buckley MM (1988): The prevalence of antibody to parvovirus B19 in England and Wales. J. Med. Microbiol. 25: 151153.

Enders M, Weidner A, Zoellner I, Searle K and Enders G (2004): Fetal morbidity and mortality after acute human parvovirus B-19 infection in pregnancy: prospective evaluation of 1018 cases. Prenatal diagnosis. 24: 513-518.

Frickhofen N and Young NS (1989): Minireview: persistent parvovirus infections in humans. Microb. Pathog. 7: 319-327.

Gillespie SM, Carter ML, Asch S, Rokor JB et al. (1990): Occupation risk of human parvovirus B19 infection for school and daycare personnel during an outbreak of erythema infectiosum. JAMA. 263: 2061-2065.

Heegaard ED, Jensen IP and Christensen J (2001): Novel PCR assay for differential detection and screening of erythrovirus B19 and erythrovirus V9. J. Med. Virol. 65: 362-367.

Hokynar K, Norja P, Laitinen H, Palomäki P, Garbarg-Chenon A, Ranki A, Hedman K and Söderlund-Venermo M (2004): Detection and differentiation of human parvovirus variants by commercial quantitative real-time PCR tests. J. Clin. Microbiol. 42: 2013-2019.

Ibrahim EA, Abdel-Wahab KSE, El-Gamal S, Abdel-Megid A and Fetouh A (1993): Parvovirus B19 in pregnancy. J. Trop. Med (Egypt). 2: 17-24.

Jong EP de, Haan TR de, Kroes ACM, Beersma MFC, Oepkes D, Walther FJ
(2006): Parvovirus B-19 infection in pregnancy. J. Clin. Virol. 36: 1-7.

Jordan JA and DeLoia JA (1999): Globside expression within the human placenta. Placenta. 20: 103-108.

Koch WC and Alder SP (1990): Detection of human parvovirus B19 DNA by using the polymerase chain reaction. J. Clin. Microbiol. 28: 65-69.

Maksheed M, Pacsa AS, Essa SS, Ahmed AA, Monem RA and Surkoul M (1999): The prevalence of antibody to human parvovirus B19 in pregnant women in Kuwait. Acta. Trop. 73: 225-229.

Nyman M, Talfvenstam T, Petersson $K$, Krassny C, Skjoldebrand-Sparre L and Broliden K (2002): Detection of human parvovirus B19 infection in first-trimester fetal loss. Obstet. Gynecol. 99: 795-798.

Nyman M, Tolfvenstam T, Petersson $K$, Krassny C, Skjoldebrand-Sparre $L$ and Broliden K (2002): Detection of human parvovirus B-19 infection in first-trimester fetal loss. Obstetrics and Gynecology. 99: 795-798.

Pattison JR and Patou G (1996): Parvoviruses. In: Barron's Medical Microbiology. $4^{\text {th }}$ edition, Barron $S$ et al. editors. University of Texas Medical Branch.

Quemelo PRV, Lima DM, Fonseca BAL de and Peres LC (2007): Detection of parvovirus B-19 infection in formalin-fixed and paraffinembedded placenta and fetal tissues. Rev. Inst. Med. Trop. S. Paulo. 49: 103-107.

Saldanha J, Lelie N, Yu MW, Heath A (2002): B19 collaborative study group. Vox Sang. 82: 24-31.

Schwarz TF, Holtentrager B and Roggendorf $M$ (1992): Prevalence of antibody to parvovirus B19 in selected groups of patients and healthy individuals. Zentralbl Bakteriol., 276: 437-442.

Schwarz TF, Jager G and Gilch S (1997): Comparison of seven commercial tests for the detection of parvovirus B19 specific IgM. Zentralbl. Bakteriol. 285: 525-530.

Servant A, Laperche S, Lallemand F, Marinho V, De Saint Maur G, Meritet JE and Garbarg Chenon A (2002): Genetic diversity within human erythroviruses: identification of three genotypes. J. Virol. 76: 9124-9134.

Siegle G and Cassinotti P (1998): Presence and significance of B19 in blood and blood products. Biologicals 26: 89-94.

Tolfvenstam T, Papadogiannakis N, Norbeck $O$, Petersson $K$ and Broliden $K$ (2001): Frequency of human parvovirus B-19 infection in intrauterine fetal death. Lancet 357: 14941497. 


\title{
انتقال عدوى فيروس البارفو ب 19 من الأم المصرية للجنين فى الثلاث شهور الأولى

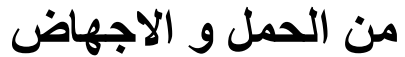

\author{
دكتور/ عاطف (بوالخير 1 / أذذ. كوكا سعد الاينا 2 \\ 1قسم الباثولوجيا الاكلينيكية, مستثفى الئير الساحل التعليمي

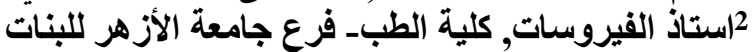

مقدمة: - 20 - n

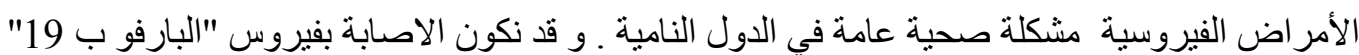

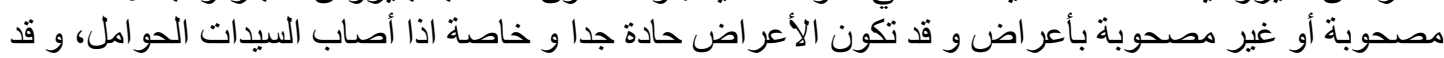

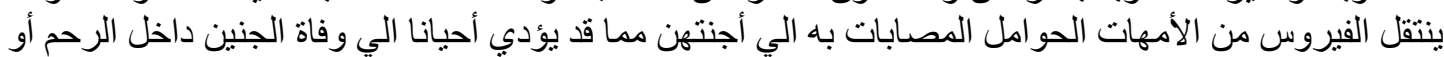

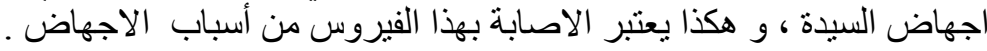

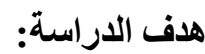

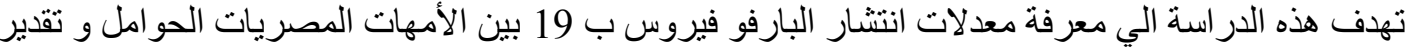

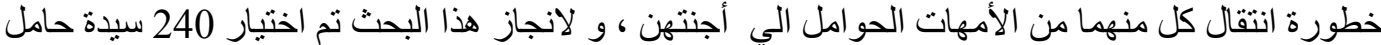

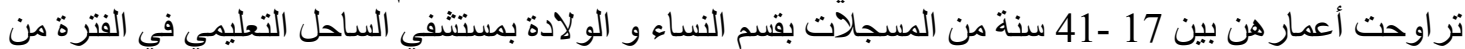

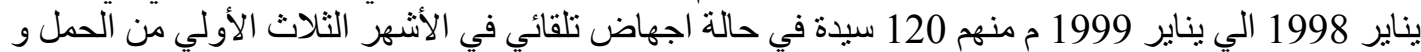
120 سيدة أخري أكملن فترة الحمل و في حالة ولادة طبيعية.

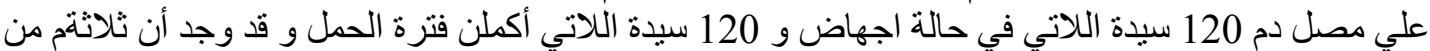

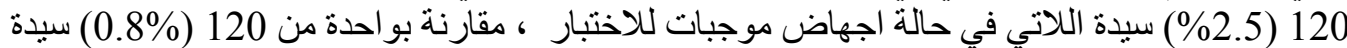

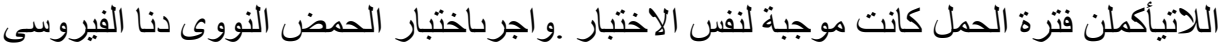

تثير الدر اسة الحالية الى أن 3/3 (100\%) سيدات اللاتى فى حالة اجهاض أعطى نسيج كل أجنتهن نتيجة

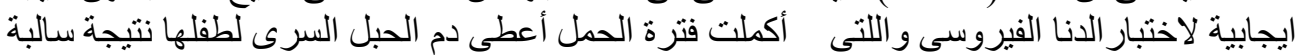

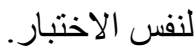

و هكذا يؤدى اصابة السيدات الحو امل بفيروس البارفو ب 19 فى الفترة الاولى من الحمل الى انتقاله الى أجنتهن مسبيا اجهاضـا تلقائيا لهن.

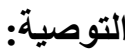

يجب اضافة اختبار الأجسام المضادة لفيروس البارفو ب 19 الي التحاليل الثخصية لأسباب الاجهاض و موت

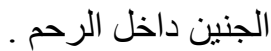

يجب عمل اختبار البارفو ب 19 علي نطاق و اسع بين الأمهات المصريات الحوامل في مختلف المناطق الجغر افية

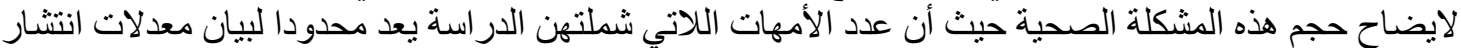

